\title{
Greek Agrifood International Trade Pre and Post Economic Crisis
}

\author{
Panagiotis Kotsios, George Kartsiotis, and Vaios Kotsios
}

\begin{abstract}
Greece has been faced with a number of severe macroeconomic problems after the breakout of the recent economic crisis. This research focuses on the Greek agrifood sector which is believed by many stakeholders to have large growth potential in terms of value added and employment. The purpose of this research is to examine the Greek agrifood sector's international trade values pre and post economic crisis, in order to record and examine performance, variations and opportunities. A total of 24 agriculture and food related $\mathrm{CN}$ 2-digit codes for periods 2004-2009 and 2010-2015 are examined and compared using various statistical metrics, in order to draw conclusions and make policy recommendations.
\end{abstract}

Index Terms - Greece, agrifood sector, international trade, $\mathrm{CN}$, crisis.

\section{INTRODUCTION}

The goal of the current research is to analyze the Greek agrifood international trade performance before and after the outbreak of the recent economic crisis. It begins with a short literature review about the role of international trade in economic growth, the Greek economic crisis, the characteristics of the Greek agrifood sector and the performance of the sector in international trade. Next is an analysis of the methodology that will be applied for the research. The analysis part presents the results of the research, whereas the conclusion part sums up the research's main findings and mentions policy recommendations and directions for future research.

\section{LITERATURE REVIEW}

International trade is widely recognized as a basic ingredient of economic development. From early authors like the mercantilists [1], Adam Smith [2], David Ricardo [3] and John Stuart Mill [4] that developed the basic international trade theories, to modern economists like Frankel \& Romer (1999) [5], Mankiw (2000) [6], Meier (2005) [7], Thompson (2006) [8], Abel \& at (2008) [9] and Krugman \& Obstfeld (2009) [10], all of them stress the importance of international trade for a country's economic growth.

Greece is an east European country with a population of 10,8 million. According to the Hellenic Statistical Authority

Manuscript received August 8, 2018; revised September 26, 2018.

P. Kotsios is with the University of Macedonia, Greece (e-mail: panagiotiskotsios@gmail.com).

G. Kartsiotis is with the Department of Applied Informatics, University of Macedonia, CO 54636 Greece (e-mail: gkartsiotis@gmail.com).

V. Kotsios is with the National Technical University of Athens, Greece (e-mail: vaioskotsios@gmail.com).
[11], Greece had a GDP of 176,02 billion $€$ in 2015 , placing it as the 46th largest economy in the world according to the World Bank [12]. The country's economy was faced with a number of serious problems during the last 7 years, a period named Greek debt crisis [13]. The Greek debt crisis started in late 2009, in the aftermath of the US financial crisis of 2007-08, triggered by structural weaknesses in the Greek economy and large state budget deficits. This led to a crisis of confidence, indicated by higher interest rates compared to the other Eurozone countries, and the country requiring bailout loans in 2010, 2012, and 2015 from the International Monetary Fund, Eurogroup, and European Central Bank. These loans were accompanied with terms for various austerity measures, tax increases, spending cuts and privatizations. Since 2008 the country's GDP has decreased by $25 \%$, unemployment rate currently exceeds $20 \%$ of the work force, while the country's national debt rose from $112 \%$ in 2008 to $180 \%$ of GDP in 2016 [11].

One of the country's structural economic problems is related with international trade. The economy's trade balance has been permanently negative for the last 2 decades, as shown in Table I.

TABLE I: GREEK TRADE BALANCE 1998-2016

\begin{tabular}{c|c|c}
\hline \multicolumn{3}{|c|}{ TABLE I: GREEK TRADE BALANCE 1998-2016 } \\
\hline Year & Billions of $€$ & \% of GDP \\
\hline 1998 & $-17,32$ & $-14,20$ \\
\hline 2000 & $-18,61$ & $-13,49$ \\
\hline 2002 & $-21,21$ & $-13,54$ \\
\hline 2004 & $-31,95$ & $-17,19$ \\
\hline 2006 & $-35,57$ & $-16,83$ \\
\hline 2008 & $-43,53$ & $-18,69$ \\
\hline 2010 & $-29,39$ & $-12,93$ \\
\hline 2012 & $-21,70$ & $-11,20$ \\
\hline 2014 & $-20,61$ & $-11,51$ \\
\hline 2016 & $-16,58$ & $-8,98$ \\
\hline
\end{tabular}

The Greek agrifood sector is considered by many domestic and foreign stakeholders and policy makers as a very good starting point for reorganizing the economy [15], [16]. Greece, due to its geographical characteristics and unique climatological conditions, produces a variety of high quality food products which have the potential to be traded in a global scale. These products can offer substantial added value to their producers and the economy in general.

However, a large number of potential markets for Greek agrifood have been unexploited so far. On the one had the importance of exports started to be recognized and valued for the survival of Greek enterprises only over the last years [17], while on the other hand, there are numerous shortcomings for 
Greek exporters: lack of national export strategy, absence of support systems and complex exports procedures [18], [19]. A characteristic example is the olive oil segment, where only $27 \%$ of Greek olive oil is standardized, against $50 \%$ in Spain and $80 \%$ in Italy [20].

On this context, the current research's goal is to examine and assess the international trade of agrifood products in Greece before and after the economic crisis, in order to observe and analyze its course and reveal product segments that constitute opportunities for import replacement and export growth.

\section{Methodology}

In order to examine and draw conclusions about the course of Greek agrifood international trade pre and post crisis, a total of 24 agriculture and food related $\mathrm{CN} 2$-digit codes were examined and compared using various statistical metrics, for the periods 2004-2009 and 2010-2015.

TABLE II: AGRIFOOD RELATED CN CODES

\begin{tabular}{|c|c|}
\hline $\begin{array}{c}2 \text { digit } \\
\mathrm{CN} \text { code }\end{array}$ & Description \\
\hline 01 & Live animals; animal products \\
\hline 02 & Meat \& edible meat offal \\
\hline 03 & $\begin{array}{l}\text { Fish and crustaceans, molluscs and other aquatic } \\
\text { invertebrates }\end{array}$ \\
\hline 04 & $\begin{array}{l}\text { Dairy produce; birds' eggs; natural honey; edible } \\
\text { products of animal origin, not elsewhere specified or } \\
\text { included }\end{array}$ \\
\hline 05 & $\begin{array}{l}\text { Products of animal origin, not elsewhere specified or } \\
\text { included }\end{array}$ \\
\hline 06 & $\begin{array}{l}\text { Live trees and other plants; bulbs, roots and the like; cut } \\
\text { flowers and ornamental foliage }\end{array}$ \\
\hline 07 & Edible vegetables and certain roots and tubers \\
\hline 08 & Edible fruit and nuts; peel of citrus fruit or melons \\
\hline 09 & Coffee, tea, maté and spices \\
\hline 10 & Cereals \\
\hline 11 & $\begin{array}{l}\text { Products of the milling industry; malt; starches; inulin; } \\
\text { wheat gluten }\end{array}$ \\
\hline 12 & $\begin{array}{l}\text { Oil seeds and oleaginous fruits; miscellaneous grains, } \\
\text { seeds and fruit; industrial or medicinal plants; straw and } \\
\text { fodder }\end{array}$ \\
\hline 13 & Lac; gums, resins and other vegetable saps and extracts \\
\hline 14 & $\begin{array}{l}\text { Vegetable plaiting materials; vegetable products not } \\
\text { elsewhere specified or included }\end{array}$ \\
\hline 15 & $\begin{array}{l}\text { Animal or vegetable fats and oils and their cleavage } \\
\text { products; prepared edible fats; animal or vegetable waxes }\end{array}$ \\
\hline 16 & $\begin{array}{l}\text { Preparations of meat, of fish or of crustaceans, molluscs } \\
\text { or other aquatic invertebrates }\end{array}$ \\
\hline 17 & Sugars \& sugar confectionery \\
\hline 18 & Cocoa \& cocoa preparations \\
\hline 19 & $\begin{array}{l}\text { Preparations of cereals, flour, starch or milk; pastrycooks' } \\
\text { products }\end{array}$ \\
\hline 20 & $\begin{array}{l}\text { Preparations of vegetables, fruit, nuts or other parts of } \\
\text { plants . }\end{array}$ \\
\hline 21 & Miscellaneous edible preparations \\
\hline 22 & Beverages, spirits and vinegar \\
\hline 23 & $\begin{array}{l}\text { Residues and waste from the food industries; prepared } \\
\text { animal fodder }\end{array}$ \\
\hline 24 & Tobacco and manufactured tobacco substitutes \\
\hline
\end{tabular}

The Combined nomenclature or $\mathrm{CN}$ is a classification system used by the European Union member states for recording exports and imports of goods [21]. It is based on the World Customs Organization's (WCO) Harmonised Commodity Description and Coding System (HS 2007). This systematic list of commodities forms the basis for international trade negotiations and is applied by most trading nations. The $\mathrm{CN}-2$ agrifood related codes that will be examined are from 1 to 24 (Table II).

The data came from the Hellenic Statistical Authority (ELSTAT) international trade database [23], but they were available only in raw form. The data, which regarded value in euros, quantity in kilos and corresponding country, had to be extracted, grouped and then summed for each year in order to make comparisons and identify trends. The total number of values in the data set was 92.136. The results of this analysis will be presented in the following pages.

\section{ANALYSIS}

The analysis of the results will be made in two distinctive parts. In the first one there is going to be a presentation and comparison of export and import trade values for CNs 01 to 24 , and in the second part there are going to be statistical comparisons regarding the course of imports, exports and trade balance, before and after the economic crisis.

\section{A. Import and Export Trade Value Analysis}

Tables III to Table VIII present the imports and exports trade values in groups of $4 \mathrm{CN}$ codes. The sums are presented in millions of euros and the examined periods are from 2004 to 2015. The period before the economic crisis was from 2004 to 2009 ( 6 years), while the period after the breakout of the crisis was from 2010 to 2015 (6 years).

Table III presents the import and export values for CNs 01-04.

CNO1 - LIVE ANIMALS; ANIMAL PRODUCTS: The total import value of live animals increased marginally pre crisis from 103,9 mil $€$ to 108,6 mil $€$, with a one year fluctuation (2007), and decreased drastically post crisis from 111,6 mil $€$ to 52,26 mil $€$, though most of the reduction occurred in the first two years of the crisis. The total export value, which is significantly lower, increased pre crisis from 2,91 mil $€$ to $8,51 \mathrm{mil} €$ as it did post crisis from 11,42 mil $€$ to 15,27 mil $€$, but we must note that the 2011 and 2012 values of almost 30 mil $€$ and 20 mil $€$ respectively were higher.

CNO2 - MEAT AND EDIBLE MEAT OFFAL: The total import value of meat and edible loaf animals increased pre crisis from 842,61 mil $€$ to $1.093,54$ mil $€$ and slightly decreased post crisis from $1.038,44$ mil $€$ to $1.017,25$ mil $€$, with minor fluctuations during 2011 and 2012. This is the agrifood sector with the largest imports in value. The total export value, which is significantly lower, increased pre crisis from 17,67 mil $€$ to $46,21 \mathrm{mil} €$ as well as post crisis from 48,79 mil $€$ to 55,64 mil $€$. In 2015 there was a trade deficit of 961 mil $€$.

CNO3 - FISH AND CRUSTACEANS, MOLLUSCS AND OTHER AQUATIC INVERTEBRATES: This is an agrifood sector with high value of imports and exports and one which Greece has a positive trade balance. The total import value of fish and crustaceans increased pre crisis from 292,72 mil $€$ to 369,51 mil $€$ reaching a maximum of 407 mil $€$ at 2007 and decreased post crisis from 341,28 mil $€$ to 329,14 mil $€$. The total export value increased pre crisis from 362,66 mil $€$ to $480,27 \mathrm{mil} €$ as it did post crisis from 534,73 mil $€$ to 590,44 
mil $€$, though we must note that the 55 mil $€$ post crisis increase is much lower than the pre crisis 117 mil $€$. The trade surplus in 2015 was 261 mil $€$.

CNO4 - DAIRY PRODUCE; BIRDS' EGGS; NATURAL HONEY; EDIBLE PRODUCTS OF ANIMAL ORIGIN, NOT ELSEWHERE SPECIFIED OR INCLUDED: This is one of the most dynamic sectors from the 24 examined in terms of import and export value. The total import value of dairy produce increased pre crisis from 623 mil $€$ to $742,51 \mathrm{mil} €$, while reaching higher levels during 2007 - 2008, and decreased post crisis from 788,91 mil $€$ to 738,42 mil $€$. The total export value which is lower, increased pre crisis from 191,22 mil $€$ to 284,47 mil $€$ as it did post crisis, with a much higher increase from $311,52 \mathrm{mil} €$ to 557,26 mil $€$. Greece's trade deficit in this sector fell from 432 mil $€$ in 2004 to 181 mil $€$ in 2015 .

TABLE III: GREEK CN01-04 TRADE VALUE OF IMPORTS AND EXPORTS

\begin{tabular}{|c|c|c|c|c|c|c|c|c|}
\hline & \multicolumn{2}{|c|}{ CN01 } & \multicolumn{2}{|c|}{ CN02 } & \multicolumn{2}{|c|}{$\mathrm{CNO3}$} & \multicolumn{2}{|c|}{ CN04 } \\
\hline YEAR & $\begin{array}{c}\mathrm{IM} \\
(\mathrm{m} €)\end{array}$ & $\begin{array}{c}\mathrm{EX} \\
(\mathrm{m} €)\end{array}$ & $\begin{array}{c}\mathrm{IM} \\
(\mathrm{m} €)\end{array}$ & $\begin{array}{c}\mathrm{EX} \\
(\mathrm{m} €)\end{array}$ & $\begin{array}{c}\mathrm{IM} \\
(\mathrm{m} €)\end{array}$ & $\begin{array}{c}\text { EX } \\
(m €)\end{array}$ & $\begin{array}{c}\mathrm{IM} \\
(\mathrm{m} €)\end{array}$ & $\begin{array}{c}\mathrm{EX} \\
(\mathrm{m} €)\end{array}$ \\
\hline 2004 & 103,90 & 2,91 & 842,61 & 17,67 & 292,72 & 362,66 & 623,44 & 191,22 \\
\hline 2005 & 113,28 & 3,30 & 972,48 & 25,78 & 320,07 & 379,24 & 657,71 & 199,79 \\
\hline 2006 & 102,22 & 3,87 & $1.051,90$ & 22,50 & 347,98 & 426,08 & 674,35 & 220,42 \\
\hline 2007 & 86,63 & 4,90 & $1.020,53$ & 37,01 & 407,18 & 454,51 & 777,57 & 265,16 \\
\hline 2008 & 105,68 & 6,19 & $1.102,52$ & 57,86 & 403,23 & 456,28 & 799,23 & 280,40 \\
\hline 2009 & 108,60 & 8,51 & $1.093,54$ & 46,21 & 369,51 & 480,27 & 742,51 & 284,47 \\
\hline 2010 & 111,64 & 11,42 & $1.038,44$ & 48,79 & 341,28 & 534,73 & 788,91 & 311,52 \\
\hline 2011 & 89,85 & 29,83 & $1.068,75$ & 53,70 & 369,79 & 609,13 & 809,04 & 336,56 \\
\hline 2012 & 60,21 & 19,82 & $1.087,11$ & 49,59 & 314,98 & 601,68 & 761,97 & 360,68 \\
\hline 2013 & 59,53 & 12,69 & $1.054,35$ & 51,08 & 292,65 & 553,16 & 828,53 & 417,61 \\
\hline 2014 & 63,61 & 14,63 & $1.039,54$ & 57,97 & 332,93 & 564,93 & 828,40 & 478,38 \\
\hline 2015 & 52,26 & 15,27 & $1.017,25$ & 55,64 & 329,14 & 590,44 & 738,42 & 557,26 \\
\hline
\end{tabular}

Source: Hellenic Statistical Authority with processing by the authors

Table IV presents the import and export values for $\mathrm{CNs}$ 05-08.

TABLE IV: GREEK CN05-08 TRADE VALUE OF IMPORTS AND EXPORTS

\begin{tabular}{|c|c|c|c|c|c|c|c|c|}
\hline & \multicolumn{2}{|c|}{ CN05 } & \multicolumn{2}{|c|}{ CN06 } & \multicolumn{2}{|c|}{$\mathrm{CN} 07$} & \multicolumn{2}{|c|}{ CN08 } \\
\hline 1LК & $\begin{array}{c}\mathrm{IM} \\
(\mathrm{m} €)\end{array}$ & $\begin{array}{c}\mathrm{EX} \\
(\mathrm{m} €)\end{array}$ & $\begin{array}{c}\mathrm{IM} \\
(\mathrm{m} €)\end{array}$ & $\begin{array}{c}\mathrm{EX} \\
(\mathrm{m} €)\end{array}$ & $\begin{array}{c}\mathrm{IM} \\
(\mathrm{m} €)\end{array}$ & $\begin{array}{c}\mathrm{EX} \\
(\mathrm{m} €)\end{array}$ & $\begin{array}{c}\mathrm{IM} \\
(\mathrm{m} €)\end{array}$ & $\begin{array}{c}\mathrm{EX} \\
(\mathrm{m} €)\end{array}$ \\
\hline 2004 & 14,22 & 5,63 & 5,89 & 5,53 & 191, & 120,20 & 305,18 & 464,02 \\
\hline 2005 & 15,24 & 3,30 & 2,36 & 5,95 & 158,92 &, 56 & 317,14 & 549,66 \\
\hline 2006 & 12 & 5,86 & 1,49 & 7,57 & 06 & 15 & 44 & 537,04 \\
\hline 2007 & 16,16 & 3,38 & 8,45 & 6,98 & 3 & 1 & 5,26 & 573,51 \\
\hline 2008 & 16,38 & 2,73 & 92,31 & 6,82 & 233,85 & 151,25 & 369,46 & 670,88 \\
\hline 2009 & 14,24 & 2,62 & 9 & 5,76 & 68 & 39 & ,94 &, 22 \\
\hline 2010 & 15,09 & 3,89 & 85,03 & 7,33 & 210,75 & 151,60 & 282,25 & 731,87 \\
\hline 2011 & 20,30 & 5,80 & 73,17 & 9,51 & 227,71 & 134,86 & 284,46 & 721,65 \\
\hline 2012 & 20,10 & 6,95 & 53,73 & 9,36 & 179,36 & 154,93 & 255,94 & 771,22 \\
\hline 2013 & 29,29 & 6,89 & 46,21 & 12,13 & 184,43 & 174,97 & 55 & 843,59 \\
\hline 2014 & 28,71 & 8,89 & 49,09 & 12,46 & 177,03 & 157,75 & 293,18 & 839,40 \\
\hline 2015 & 26,87 & 7,80 & 51,95 & 13,31 & 201,74 & 155,00 & 325,80 & 814,85 \\
\hline
\end{tabular}

Source: Hellenic Statistical Authority with processing by the authors

CN05 - PRODUCTS OF ANIMAL ORIGIN, NOT ELSEWHERE SPECIFIED OR INCLUDED: This is a sector with relatively low import and export values. The total import value of products of animal origin has remained stable post crisis with minor fluctuations around 14 mil $€$ and increased significantly post crisis from 15 mil $€$ to 26,87 mil $€$. The total export value which is lower, decreased pre crisis from 5,53 mil $€$ to 2,62 mil $€$ but increased post crisis from 3,89 mil $€$ to 7,80 mil €.

CNO6 - LIVE TREES AND OTHER PLANTS; BULBS, ROOTS AND THE LIKE; CUT FLOWERS AND ORNAMENTAL FOLIAGE: The total import value of live trees and other plants increased pre crisis from 85,89 mil $€$ to 99,70 mil $€$ and decreased drastically post crisis from 85 mil $€$ to $52 \mathrm{mil} €$. The total export value is considerably lower and remained stable pre crisis around 6 mil $€$. Post crisis it increased from 7,33 mil $€$ to 13,31 mil $€$. In 2015 there was a trade deficit of 39 mil $€$.

CNO7 - EDIBLE VEGETABLES AND CERTAIN ROOTS $A N D$ TUBERS: The total import value of edible vegetables increased pre-crisis from 191 mil $€$ to 226,68 mil $€$ with a one year abrupt decrease to 159 mil $€$ (in 2005\} and decreased post crisis from 210,75 mil $€$ to 201,74 mil $€$, with most of the reduction occurring at $2011-2012$. The total export value is lower and increased pre crisis from 120 mil $€$ to 134 mil $€$ as it did post crisis from $151,60 \mathrm{mil} €$ to $155 \mathrm{mil} €$. The trade deficit decreased from 71 mil $€$ in 2004 to 47 mil $€$ in 2015.

CNO8 - EDIBLE FRUIT AND NUTS; PEEL OF CITRUS FRUIT OR MELONS: This is the second agrifood sector in which Greece has a trade surplus. The total import of edible fruits increased pre crisis from 305 mil $€$ to 332 mil $€$ as well as post crisis from $282 \mathrm{mil} €$ to 326 mil $€$. The total export value, increased pre-crisis from 464 mil $€$ to 624,22 mil $€$ and this trend continued post crisis from 731,87 mil $€$ to almost 815 mil $€$, so we notice a continuously expanding positive balance. The trade surplus in 2015 was 489 mil $€$.

Table $\mathrm{V}$ presents the import and export values for $\mathrm{CNs}$ $09-12$.

CNO9 - COFFEE, TEA, MATÉ AND SPICES: The total import value of coffee, tea, maté and spices increased pre-crisis from 71 mil $€$ to 129,46 mil $€$ and this trend continued post crisis with an increase from 129 mil $€$ to 223 mil $€$. The total export value which is lower, increased slightly pre crisis from 8,39 mil $€$ to 10,85 mil $€$ as it did post crisis from 11 mil $€$ to 25,35 mil $€$. The trade deficit increased substantially from 63 mil $€$ in 2004 to 198 mil $€$ in 2015 .

CN10 - CEREALS: The total import value of cereals decreased pre-crisis from 326 mil $€$ to 262,38 mil $€$ with great fluctuations and increased post crisis from 316 mil $€$ to 333,88 mil $€$. The total export value, which is lower, increased significantly pre crisis from 45,20 mil $€$ to 205,38 
mil $€$ and decreased post crisis from almost 159 mil $€$ to 111,72 mil $€$, despite the initial 2010 - 2012 increase.

CN11 - PRODUCTS OF THE MILLING INDUSTRY; MALT; STARCHES; INULIN; WHEAT GLUTEN: The total import value of milling products increased pre-crisis from almost 34 mil $€$ to $57 \mathrm{mil} €$ as it did post crisis from $58,57 \mathrm{mil}$ $€$ to $62 \mathrm{mil} €$. The total export value which is lower, increased pre crisis from $11,68 \mathrm{mil} €$ to $18,18 \mathrm{mil} €$ and the trend continued post crisis from 15,63 mil $€$ to 24 mil $€$ with a great increase of 8 mil $€$ occurring at 2015. The trade balance in 2015 was -38 mil $€$.

CN12 - OIL SEEDS AND OLEAGINOUS FRUITS; MISCELLANEOUS GRAINS, SEEDS AND FRUIT; INDUSTRIAL OR MEDICINAL PLANTS; STRAW AND FODDER: The total import value of oil seeds et al increased pre-crisis from 194,29 mil $€$ to 232,41 mil $€$ after a maximum of $281 \mathrm{mil} €$ at 2008 and this continued post crisis from 213 mil $€$ to 257 mil $€$. The total export value, which is lower, increased pre crisis from 58,43 mil $€$ to 67,46 mil $€$ as it did post crisis from 72,52 mil $€$ to 102,59 mil $€$. The trade deficit in 2015 was 154 mil $€$.

Table VI presents the import and export values for CNs 13-16.

CN13 - LAC; GUMS, RESINS AND OTHER VEGETABLE SAPS AND EXTRACTS: The total import value of lac gums, resins and other vegetable saps increased pre crisis from 7 mil $€$ to 10,67 mil $€$ and reached 12 mil $€$ post crisis with minor fluctuations. The total export value, which is slightly lower, increased pre crisis from $5,22 \mathrm{mil} €$ to $7,8 \mathrm{mil} €$ as it did post crisis from 7,67 mil $€$ to 11,59 mil $€$ converging to the import levels. The trade balance in 2015 was almost equalized.

CN14 - VEGETABLE PLAITING MATERIALS; VEGETABLE PRODUCTS NOT ELSEWHERE SPECIFIED $O R$ INCLUDED: The total import value of vegetable plaiting materials remained on a low level of 2,33 mil $€$ pre crisis and increased from 1,51 mil $€$ to 7,44 mil $€$ post crisis, with a high rate of increase during the last two years of the crisis. The total export value remained on very low levels post crisis and slightly increased post crisis reaching 2,78 mil $€$. The trade deficit was 4,66 mil $€$ in 2015 .

TABLE V: GREEK CNO9-12 TRADE VALUE OF IMPORTS AND EXPORTS

\begin{tabular}{|c|c|c|c|c|c|c|c|c|}
\hline & \multicolumn{2}{|c|}{ CN09 } & \multicolumn{2}{|c|}{ CN10 } & \multicolumn{2}{|c|}{ CN11 } & \multicolumn{2}{|c|}{ CN12 } \\
\hline YEAR & $\begin{array}{c}\mathrm{IM} \\
(\mathrm{m} €)\end{array}$ & $\begin{array}{c}\mathrm{EX} \\
(\mathrm{m} €)\end{array}$ & $\begin{array}{c}\mathrm{IM} \\
(\mathrm{m} €)\end{array}$ & $\begin{array}{c}\mathrm{EX} \\
(\mathrm{m} €)\end{array}$ & $\begin{array}{c}\mathrm{IM} \\
(\mathrm{m} €)\end{array}$ & $\begin{array}{c}\mathrm{EX} \\
(\mathrm{m} €)\end{array}$ & $\begin{array}{c}\mathrm{IM} \\
(\mathrm{m} €)\end{array}$ & $\begin{array}{c}\mathrm{EX} \\
(\mathrm{m} €)\end{array}$ \\
\hline 2004 & 70,98 & 8,39 & 326,09 & 45,20 & 33,91 & 11,68 & 194,29 & 58,43 \\
\hline 2005 & 82,67 & 7,13 & 273,68 & 118,75 & 32,63 & 13,33 & 172,77 & 63,75 \\
\hline 2006 & 87,96 & 6,29 & 327,27 & 109,67 & 34,39 & 9,84 & 169,56 & 62,92 \\
\hline 2007 & 111,53 & 8,19 & 497,00 & 105,77 & 51,38 & 13,93 & 203,73 & 59,84 \\
\hline 2008 & 132,88 & 10,90 & 443,49 & 168,97 & 62,50 & 16,78 & 281,08 & 84,96 \\
\hline 2009 & 129,46 & 10,85 & 262,38 & 205,38 & 57,03 & 18,18 & 232,41 & 67,46 \\
\hline 2010 & 129,25 & 10,98 & 316,13 & 158,90 & 58,57 & 15,63 & 212,97 & 72,52 \\
\hline 2011 & 170,15 & 16,60 & 429,52 & 171,73 & 80,76 & 15,63 & 215,49 & 72,21 \\
\hline 2012 & 175,99 & 17,83 & 341,64 & 180,00 & 65,82 & 15,69 & 253,73 & 82,98 \\
\hline 2013 & 169,22 & 17,49 & 361,55 & 118,59 & 72,98 & 17,53 & 275,14 & 85,78 \\
\hline 2014 & 191,22 & 16,14 & 301,71 & 178,77 & 65,34 & 16,15 & 262,86 & 91,31 \\
\hline 2015 & 222,94 & 25,35 & 333,88 & 111,72 & 61,99 & 24,00 & 257,10 & 102,59 \\
\hline
\end{tabular}

Source: Hellenic Statistical Authority with processing by the authors

TABLE VI: GREEK CN13-16 TRADE VALUE OF IMPORTS AND EXPORTS

\begin{tabular}{c|c|c|c|c|c|c|c|c}
\hline & \multicolumn{2}{|c|}{ CN13 } & \multicolumn{2}{c|}{ CN14 } & \multicolumn{2}{c}{ CN15 } & \multicolumn{2}{c}{ CN16 } \\
\hline YEAR & $\begin{array}{c}\text { IM } \\
(\mathrm{m} €)\end{array}$ & $\begin{array}{c}\text { EX } \\
(\mathrm{m} €)\end{array}$ & $\begin{array}{c}\mathrm{IM} \\
(\mathrm{m} €)\end{array}$ & $\begin{array}{c}\text { EX } \\
(\mathrm{m} €)\end{array}$ & $\begin{array}{c}\text { IM } \\
(\mathrm{m} €)\end{array}$ & $\begin{array}{c}\text { EX } \\
(\mathrm{m} €)\end{array}$ & $\begin{array}{c}\text { IM } \\
(\mathrm{m} €)\end{array}$ & $\begin{array}{c}\text { EX } \\
(\mathrm{m} €)\end{array}$ \\
\hline 2004 & 7,03 & 5,22 & 2,33 & 0,94 & 161,02 & 205,20 & 118,71 & 37,34 \\
\hline 2005 & 6,67 & 5,46 & 0,95 & 0,61 & 146,78 & 473,23 & 122,39 & 42,40 \\
\hline 2006 & 7,54 & 5,42 & 0,67 & 0,41 & 178,59 & 542,05 & 133,03 & 47,35 \\
\hline 2007 & 10,52 & 8,49 & 1,42 & 0,43 & 247,80 & 421,12 & 141,30 & 70,15 \\
\hline 2008 & 11,94 & 6,66 & 2,05 & 0,64 & 330,68 & 380,66 & 156,79 & 69,59 \\
\hline 2009 & 10,67 & 7,80 & 1,78 & 0,50 & 254,02 & 340,06 & 161,54 & 67,28 \\
\hline 2010 & 10,89 & 7,67 & 1,51 & 0,24 & 277,51 & 342,15 & 166,97 & 71,15 \\
\hline 2011 & 12,94 & 8,68 & 1,70 & 0,13 & 288,28 & 391,30 & 155,95 & 43,03 \\
\hline 2012 & 13,22 & 9,83 & 1,46 & 2,47 & 317,20 & 433,20 & 142,53 & 27,67 \\
\hline 2013 & 11,91 & 9,49 & 1,96 & 0,20 & 293,40 & 612,29 & 146,88 & 30,62 \\
\hline 2014 & 14,30 & 10,18 & 5,83 & 0,29 & 306,92 & 351,03 & 143,55 & 28,89 \\
\hline 2015 & 12,04 & 11,59 & 7,44 & 2,78 & 290,77 & 755,21 & 131,91 & 27,67 \\
\hline
\end{tabular}

Source: Hellenic Statistical Authority with processing by the authors

CN15 - ANIMAL OR VEGETABLE FATS AND OILS AND THEIR CLEAVAGE PRODUCTS; PREPARED EDIBLE FATS; ANIMAL OR VEGETABLE WAXES: This is the third out of the $24 \mathrm{CN}$ codes with a trade surplus. The total import value of animal or vegetables fats increased pre crisis from 161 mil $€$ to 254 mil $€$ and decreased post crisis from 277,51 mil $€$ to 290,77 mil $€$. The total export value, which is higher, increased pre crisis from 205,2 mil $€$ to $340 \mathrm{mil} €$ and increased rapidly post crisis from 342,15 mil $€$ to $755,21 \mathrm{mil} €$. The trade surplus in 2015 was 464,44 mil €.
CN16 - PREPARATIONS OF MEAT, OF FISH OR OF CRUSTACEANS, MOLLUSCS OR OTHER AQUATIC INVERTEBRATES: The total import value of preparations of meat increased steadily pre crisis from 118,71 mil $€$ to 161,54 mil $€$ and decreased post crisis from 167 mil $€$ to 132 mil $€$. The total export value, which is lower, increased pre crisis from 37,34 mil $€$ to 67,28 mil $€$ and decreased significantly post crisis from 71 mil $€$ to 27,67 mil $€$.

Table VII presents the import and export values for CNs 17-20. 
TABLE VII: GREEK CN17-20 TRADE VALUE OF IMPORTS AND EXPORTS

\begin{tabular}{c|c|c|c|c|c|c|c|c}
\hline & \multicolumn{2}{|c|}{ CN17 } & \multicolumn{2}{c|}{ CN18 } & \multicolumn{2}{c|}{ CN19 } & \multicolumn{2}{c}{ CN20 } \\
\hline YEAR & $\begin{array}{c}\text { IM } \\
(\mathrm{m} €)\end{array}$ & $\begin{array}{c}\text { EX } \\
(\mathrm{m} €)\end{array}$ & $\begin{array}{c}\text { IM } \\
(\mathrm{m} €)\end{array}$ & $\begin{array}{c}\mathrm{EX} \\
(\mathrm{m} €)\end{array}$ & $\begin{array}{c}\text { IM } \\
(\mathrm{m} €)\end{array}$ & $\begin{array}{c}\text { EX } \\
(\mathrm{m} €)\end{array}$ & $\begin{array}{c}\text { IM } \\
(\mathrm{m} €)\end{array}$ & $\begin{array}{c}\text { EX } \\
(\mathrm{m} €)\end{array}$ \\
\hline 2004 & 137,61 & 22,03 & 138,16 & 13,88 & 241,05 & 105,62 & 197,58 & 494,41 \\
\hline 2005 & 116,16 & 42,72 & 139,09 & 12,63 & 246,12 & 113,61 & 188,51 & 583,92 \\
\hline 2006 & 138,88 & 87,46 & 150,93 & 11,07 & 269,93 & 126,44 & 206,28 & 650,58 \\
\hline 2007 & 215,06 & 41,45 & 158,83 & 11,62 & 281,75 & 147,29 & 249,69 & 738,44 \\
\hline 2008 & 230,87 & 61,52 & 178,03 & 12,12 & 324,69 & 156,35 & 249,27 & 726,58 \\
\hline 2009 & 183,89 & 80,14 & 185,27 & 12,95 & 302,41 & 147,41 & 223,76 & 681,26 \\
\hline 2010 & 218,29 & 122,29 & 190,74 & 16,28 & 298,91 & 144,35 & 216,79 & 794,97 \\
\hline 2011 & 289,68 & 113,79 & 163,46 & 18,82 & 292,49 & 152,13 & 224,20 & 779,54 \\
\hline 2012 & 287,21 & 109,68 & 148,79 & 23,61 & 291,56 & 152,49 & 218,44 & 882,22 \\
\hline 2013 & 275,35 & 85,96 & 151,22 & 25,27 & 303,25 & 151,90 & 208,36 & 882,63 \\
\hline 2014 & 220,35 & 62,27 & 170,99 & 26,05 & 301,90 & 163,28 & 214,44 & 892,59 \\
\hline 2015 & 199,38 & 61,86 & 166,74 & 34,12 & 288,60 & 189,64 & 226,10 & 942,11 \\
\hline
\end{tabular}

Source: Hellenic Statistical Authority with processing by the authors

TABLE VIII: GREEK CN21-24 TRADE VALUE OF IMPORTS AND EXPORTS

\begin{tabular}{c|c|c|c|c|c|c|c|c}
\hline & \multicolumn{2}{|c|}{ CN21 } & \multicolumn{2}{c|}{ CN22 } & \multicolumn{2}{c}{ CN23 } \\
\hline YEAR & $\begin{array}{c}\text { IM } \\
(\mathrm{m} €)\end{array}$ & $\begin{array}{c}\text { EX } \\
(\mathrm{m} €)\end{array}$ & $\begin{array}{c}\text { IM } \\
(\mathrm{m} €)\end{array}$ & $\begin{array}{c}\text { EX } \\
(\mathrm{m} €)\end{array}$ & $\begin{array}{c}\text { IM } \\
(\mathrm{m} €)\end{array}$ & $\begin{array}{c}\text { EX } \\
(\mathrm{m} €)\end{array}$ & $\begin{array}{c}\text { IM } \\
(\mathrm{m} €)\end{array}$ & $\begin{array}{c}\text { EX } \\
(\mathrm{m} €)\end{array}$ \\
\hline 2004 & 226,97 & 68,29 & 392,51 & 163,74 & 272,45 & 28,88 & 298,64 & 365,62 \\
\hline 2005 & 229,72 & 76,38 & 424,76 & 150,79 & 297,46 & 31,32 & 313,32 & 431,39 \\
\hline 2006 & 247,52 & 83,50 & 425,49 & 154,68 & 298,41 & 33,00 & 316,27 & 377,14 \\
\hline 2007 & 279,39 & 101,49 & 431,35 & 171,99 & 380,16 & 37,09 & 348,64 & 364,39 \\
\hline 2008 & 327,22 & 118,15 & 452,78 & 188,19 & 414,23 & 54,21 & 341,37 & 446,01 \\
\hline 2009 & 337,71 & 125,72 & 447,95 & 189,26 & 376,91 & 45,77 & 417,47 & 435,51 \\
\hline 2010 & 343,61 & 153,35 & 391,72 & 187,16 & 384,32 & 42,82 & 322,65 & 391,37 \\
\hline 2011 & 360,10 & 154,70 & 335,16 & 216,92 & 351,44 & 42,25 & 263,12 & 389,60 \\
\hline 2012 & 353,14 & 153,81 & 299,01 & 222,35 & 348,74 & 47,98 & 234,26 & 427,73 \\
\hline 2013 & 371,37 & 173,25 & 287,85 & 212,88 & 408,86 & 58,94 & 236,01 & 392,01 \\
\hline 2014 & 389,21 & 183,07 & 290,92 & 218,26 & 414,43 & 59,03 & 245,43 & 386,40 \\
\hline 2015 & 369,87 & 207,61 & 282,82 & 231,06 & 411,21 & 56,56 & 302,13 & 449,85 \\
\hline
\end{tabular}

Source: Hellenic Statistical Authority with processing by the authors

CN17 - SUGARS AND SUGAR CONFECTIONERY: The total import value of sugars and sugar confectionary increased pre crisis from 137,61 mil $€$ to 183,89 mil $€$, though we must a note that it reached higher levels during $2007-2008$, and decreased post crisis from 218,29 mil $€$ to 199,38 mil $€$, with most of the decrease occurring in the last two years of the crisis. The total export value, which is lower, increased pre crisis from 22,03 mil $€$ to 80,14 mil $€$ and decreased post crisis from 122,29 mil $€$ to 61,86 mil $€$.

CN18 - COCOA AND COCOA PREPARATIONS: The total import value of preparations of cocoa and cocoa preparations increased pre crisis with a constant rate from 138,16 mil $€$ to 185,27 mil $€$, and decreased post crisis from 190,74 mil $€$ to 166,74 mil $€$.. The total export value, which is lower, decreased marginally pre crisis from 13,88 mil $€$ to 12,95 mil $€$ and increased post crisis from 16,28 mil $€$ to 34,12 mil $€$.

CN19 - PREPARATIONS OF CEREALS, FLOUR, STARCH OR MILK; PASTRYCOOKS' PRODUCTS: The total import value of preparations of cereals increased pre crisis from 241 mil $€$ to 302,41 mil $€$, with a 2008 peak of 324,69 mil $€$ and decreased post crisis from almost 299 mil $€$ to 288,6 mil $€$. The total export value, which is lower, increased pre crisis from 105,62 mil $€$ to $147,41 \mathrm{mil} €$ and after a one year decrease at 2010 reaching 144,35 mil $€$, increased post crisis to 189,64 mil $€$.

CN2O - PREPARATIONS OF VEGETABLES, FRUIT, NUTS OR OTHER PARTS OF PLANTS: This is a particularly dynamic sector and the 4th that Greece has a trade surplus.
The total import value of preparations of vegetables increased pre crisis from 197,58 mil $€$ to 223,76 mil $€$ as well as post crisis from 216,79 mil $€$ to 226,1 mil $€$. The total export value, which is significantly higher, increased pre crisis from 494,41 mil $€$ to 681,26 mil $€$, as it did post crisis from 795 mil $€$ to 942,11 mil $€$. The trade surplus was 716 mil $€$ in 2015 .

Table 8 presents the import and export values for $\mathrm{CNs}$ 21-24.

CN21 - MISCELLANEOUS EDIBLE PREPARATIONS: The total import value of miscellaneous edible preparations increased pre crisis from 227 mil $€$ to 337,71 mil $€$ and despite the crisis this trend continued post 2009 from 343,61 mil $€$ to almost 370 mil $€$. The total export value, which is lower, increased pre crisis from 68,29 mil $€$ to $125,72 \mathrm{mil} €$ as it did post crisis from 153,35 mil $€$ to 207,61 mil $€$. The trade deficit in 2015 was 162,26 mil $€$.

CN22 - BEVERAGES, SPIRITS AND VINEGAR: The total import value of beverages, spirits and vinegar increased pre crisis from 392,51 mil $€$ to 447,95 mil $€$ but decreased drastically post crisis from 392,72 mil $€$ to 282,82 mil $€$. The total export value, which is lower, increased pre crisis from 163,74 mil $€$ to 189,26 mil $€$ as it did post crisis from 187,16 mil $€$ to 231,06 mil $€$. The trade balance was $-51,76$ mil $€$ in 2015.

CN23 - RESIDUES AND WASTE FROM THE FOOD INDUSTRIES; PREPARED ANIMAL FODDER: The total import value of residues increased pre crisis from $272,45 \mathrm{mil}$ $€$ to almost 377 mil $€$ as well as post crisis from 384,32 mil $€$ to 411,21 mil $€$, after an initial decrease during 2011 and 2012. 
The total export value, which is considerably lower, increased pre crisis from 28,88 mil $€$ to 45,77 mil $€$ as it did post crisis from 42,82 mil $€$ to 56,56 mil $€$. The trade deficit was 354,65 mil $€$ in 2015 .

CN24 - TOBACCO AND MANUFACTURED TOBACCO SUBSTITUTES: The total import value of tobacco increased pre crisis from 298,64 mil $€$ to 417,47 mil $€$ but decreased drastically post crisis from 322,65 mil $€$ to 302,13 mil $€$. The total export value, is higher and increased pre crisis from 366,62 mil $€$ to $435,51 \mathrm{mil} €$ and after a reduction at 2010 it increased post crisis reaching almost 450 mil $€$. The trade surplus was 147,72 mil $€$ in 2015 .

\section{B. Pre and Post Crisis Comparisons \& Trade Balances}

Apart from looking individually at the course of each $\mathrm{CN}$-sector's import and export value, it is also useful to calculate period averages and record percentage changes pre and post crisis (Table IX). This method can allow performance comparisons between time periods.

TABLE IX: PRE AND POST CRISIS CN01-24 IMPORT AND EXPORT TRADE VALUE AVERAGES COMPARISON

\begin{tabular}{|c|c|c|c|c|c|c|}
\hline & \multicolumn{6}{|c|}{ AVERAGE TRADE VALUE (MIL. €) } \\
\hline & \multicolumn{3}{|c|}{ IMPORTS } & \multicolumn{3}{|c|}{ EXPORTS } \\
\hline & Pre crisis & Post crisis & \multirow{2}{*}{$\%$ change } & Pre crisis & Post crisis & \multirow{2}{*}{$\%$ change } \\
\hline $\mathrm{CN}$ & $2004-2009$ & $2010-2015$ & & $2004-2009$ & $2010-2015$ & \\
\hline 01 & 103,39 & 72,92 & $-29,47$ & 4,95 & 17,28 & 249,09 \\
\hline 02 & $1.013,93$ & $1.050,91$ & 3,65 & 34,50 & 52,80 & 53,04 \\
\hline 03 & 356,78 & 330,13 & $-7,47$ & 426,51 & 575,68 & 34,97 \\
\hline 04 & 712,47 & 792,54 & 11,24 & 240,24 & 410,33 & 70,80 \\
\hline 05 & 15,13 & 23,39 & 54,59 & 3,92 & 6,71 & 71,17 \\
\hline 06 & 86,70 & 59,86 & $-30,96$ & 6,44 & 10,68 & 65,84 \\
\hline 07 & 206,32 & 196,84 & $-4,59$ & 138,37 & 154,85 & 11,91 \\
\hline 08 & 325,57 & 284,86 & $-12,50$ & 569,89 & 787,10 & 38,11 \\
\hline 09 & 102,58 & 176,46 & 72,02 & 8,63 & 17,40 & 101,62 \\
\hline 10 & 354,98 & 347,40 & $-2,14$ & 125,62 & 153,29 & 22,03 \\
\hline 11 & 45,31 & 67,58 & 49,15 & 13,96 & 17,44 & 24,93 \\
\hline 12 & 208,97 & 246,22 & 17,83 & 66,23 & 84,56 & 27,68 \\
\hline 13 & 9,06 & 12,55 & 38,52 & 6,51 & 9,57 & 47,00 \\
\hline 14 & 1,53 & 3,32 & 116,99 & 0,59 & 1,02 & 72,88 \\
\hline 15 & 219,82 & 295,68 & 34,51 & 393,72 & 480,86 & 22,13 \\
\hline 16 & 138,96 & 147,97 & 6,48 & 55,68 & 38,17 & $-31,45$ \\
\hline 17 & 170,41 & 248,38 & 45,75 & 55,89 & 92,64 & 65,75 \\
\hline 18 & 158,38 & 165,32 & 4,38 & 12,38 & 24,03 & 94,10 \\
\hline 19 & 277,66 & 296,12 & 6,65 & 132,79 & 158,96 & 19,71 \\
\hline 20 & 219,18 & 218,06 & $-0,51$ & 645,87 & 862,34 & 33,52 \\
\hline 21 & 274,75 & 364,55 & 32,68 & 95,59 & 170,97 & 78,86 \\
\hline 22 & 429,14 & 314,58 & $-26,70$ & 169,78 & 214,77 & 26,50 \\
\hline 23 & 339,94 & 386,50 & 13,70 & 38,38 & 51,27 & 33,59 \\
\hline 24 & 339,29 & 267,27 & $-21,23$ & 403,35 & 406,16 & 0,70 \\
\hline
\end{tabular}

TABLE X: PRE AND POST CRISIS CN01-24 IMPORT AND EXPORT TRADE VALUE STANDARD DEVIATION

\begin{tabular}{|c|c|c|c|c|}
\hline & \multicolumn{2}{|c|}{ IMPORTS } & \multicolumn{2}{|c|}{ EXPORTS } \\
\hline $\mathrm{CN}$ & $2004-2009$ & $2010-2015$ & 2004-2009 & $2010-2015$ \\
\hline 01 & 9,09 & 22,98 & 2,11 & 6,79 \\
\hline 02 & 96,69 & 24,73 & 15,44 & 3,60 \\
\hline 03 & 45,58 & 25,85 & 46,63 & 29,37 \\
\hline 04 & 70,78 & 36,69 & 41,53 & 93,75 \\
\hline 05 & 0,96 & 5,74 & 1,44 & 1,72 \\
\hline 06 & 9,35 & 15,58 & 0,80 & 2,30 \\
\hline 07 & 29,79 & 20,11 & 16,78 & 12,83 \\
\hline 08 & 30,11 & 24,03 & 71,92 & 53,45 \\
\hline 09 & 25,80 & 30,66 & 1,90 & 4,62 \\
\hline 10 & 94,65 & 45,22 & 55,51 & 30,55 \\
\hline 11 & 13,26 & 8,04 & 3,11 & 3,30 \\
\hline 12 & 42,09 & 25,84 & 9,71 & 11,59 \\
\hline 13 & 2,25 & 1,19 & 1,38 & 1,33 \\
\hline 14 & 0,64 & 2,63 & 0,20 & 1,25 \\
\hline 15 & 70,34 & 14,17 & 116,33 & 166,69 \\
\hline 16 & 17,62 & 12,10 & 14,96 & 17,18 \\
\hline 17 & 46,57 & 40,08 & 25,08 & 26,58 \\
\hline 18 & 19,73 & 15,20 & 1,00 & 6,24 \\
\hline 19 & 32,36 & 6,04 & 20,62 & 16,20 \\
\hline 20 & 26,19 & 6,50 & 92,88 & 62,42 \\
\hline 21 & 48,56 & 15,95 & 23,29 & 21,74 \\
\hline 22 & 21,41 & 42,19 & 16,42 & 14,87 \\
\hline 23 & 57,60 & 30,17 & 9,76 & 7,88 \\
\hline 24 & 42,57 & 37,00 & 38,13 & 26,30 \\
\hline
\end{tabular}

By comparing the six year average values of imports pre and post crisis, firstly we notice that in most $\mathrm{CN}$ categories there is an increase. In detail, we observe that the import value increased in $15 \mathrm{CN}$ codes and decreased in 9. Increases varied from $3,65 \%$ (CN02- Meat \& edible meat offal) to $116 \%$ (CN14-Vegetable plaiting materials). Reductions varied from $-0,51 \%$ (CN20 Preps of vegs, fruits, nuts, etc) to $-29 \%$ (CN01- Live animals).

Export average values also grew in 23 out of $24 \mathrm{CN}$ categories. Increases varied from $0,70 \%$ (CN24-Tobacoo) to $249 \%$ (CN01-Live animals). Sectors that combine large export values and increases are CN03 Fish and crustaceans, CN04 Dairy produce, CN08 Edible fruit and nuts, CN015 Animal or vegetable fats and oils CN20 Preparations of vegetables, fruit, nuts or other parts of plants, CN21 Miscellaneous edible preparations, CN22 Beverages, spirits and vinegar. The only reduction was $-31 \%$ in CN16- Ed. prep. of meat, fish, crustaceans, etc. Table $\mathrm{X}$ presents the import and export standard deviation of averages in the pre and post crisis period.

Large standard deviations can be noticed for imports in CN02, CN04, CN10, CN15, CN17 and CN23. In general for imports in the pre-crisis periods the standard deviations are 
larger than the post crisis. For exports large standard deviations pre crisis can be noticed in CN08, CN10, CN15 and CN20, while post crisis in CN04, CN10, CN15 and CN20.
Another useful indicator is to examine each CN category's trade balance (Table XI).

TABLE 11: CN01-24 TRADE BALANCES

\begin{tabular}{|c|c|c|c|c|c|c|c|c|c|c|c|c|}
\hline & CN01 & CN02 & CN03 & CN04 & CN05 & CN06 & CN07 & CN08 & CN09 & CN10 & CN11 & CN12 \\
\hline 2004 & $-100,99$ & $-824,94$ & 69,94 & $-432,22$ & $-8,59$ & $-80,35$ & $-71,07$ & 158,84 & $-62,59$ & $-280,89$ & $-22,24$ & $-135,86$ \\
\hline 2005 & $-109,99$ & $-946,7$ & 59,17 & $-457,92$ & $-11,94$ & $-66,41$ & $-41,36$ & 232,51 & $-75,53$ & $-154,92$ & $-19,3$ & $-109,02$ \\
\hline 2006 & $-98,34$ & $-1029,4$ & 78,1 & $-453,94$ & $-8,68$ & $-73,92$ & $-39,36$ & 252,6 & $-81,66$ & $-217,6$ & $-24,55$ & $-106,63$ \\
\hline 2007 & $-81,72$ & $-983,52$ & 47,33 & $-512,41$ & $-12,78$ & $-81,47$ & $-81,01$ & 228,25 & $-103,34$ & $-391,23$ & $-37,45$ & $-143,89$ \\
\hline 2008 & $-99,49$ & $-1044,67$ & 53,06 & $-518,83$ & $-13,65$ & $-85,49$ & $-82,6$ & 301,42 & $-121,97$ & $-274,52$ & $-45,72$ & $-196,13$ \\
\hline 2009 & $-100,08$ & $-1047,33$ & 110,77 & $-458,03$ & $-11,62$ & $-93,94$ & $-92,28$ & 292,29 & $-118,62$ & -57 & $-38,85$ & $-164,95$ \\
\hline 2010 & $-100,22$ & $-989,64$ & 193,45 & $-477,38$ & $-11,2$ & $-77,71$ & $-59,15$ & 449,62 & $-118,27$ & $-157,24$ & $-42,95$ & $-140,45$ \\
\hline 2011 & $-60,03$ & $-1015,05$ & 239,35 & $-472,48$ & $-14,5$ & $-63,66$ & $-92,84$ & 437,19 & $-153,55$ & $-257,79$ & $-65,14$ & $-143,28$ \\
\hline 2012 & $-40,4$ & $-1037,52$ & 286,7 & $-401,29$ & $-13,15$ & $-44,37$ & $-24,43$ & 515,27 & $-158,16$ & $-161,63$ & $-50,13$ & $-170,75$ \\
\hline 2013 & $-47,24$ & $-1003,27$ & 260,51 & $-410,92$ & $-22,39$ & $-34,08$ & $-9,45$ & 576,04 & $-151,73$ & $-242,96$ & $-55,46$ & $-189,36$ \\
\hline 2014 & $-48,98$ & $-981,57$ & 232 & $-350,02$ & $-19,82$ & $-36,63$ & $-19,28$ & 546,22 & $-175,07$ & $-122,94$ & $-49,19$ & $-171,55$ \\
\hline \multirow[t]{2}{*}{2015} & $-36,99$ & $-961,61$ & 261,3 & $-181,16$ & $-19,07$ & $-38,64$ & $-46,75$ & 489,05 & $-197,59$ & $-222,15$ & $-37,99$ & $-154,52$ \\
\hline & CN13 & CN14 & CN15 & CN16 & CN17 & CN18 & CN19 & CN20 & CN21 & CN22 & CN23 & CN24 \\
\hline 2004 & $-1,81$ & $-1,38$ & 44,18 & $-81,37$ & $-115,58$ & $-124,27$ & $-135,43$ & 296,83 & $-158,69$ & $-228,78$ & $-243,57$ & 66,98 \\
\hline 2005 & $-1,21$ & $-0,34$ & 326,46 & $-79,99$ & $-73,44$ & $-126,46$ & $-132,51$ & 395,4 & $-153,34$ & $-273,97$ & $-266,14$ & 118,08 \\
\hline 2006 & $-2,11$ & $-0,26$ & 363,46 & $-85,68$ & $-51,42$ & $-139,86$ & $-143,49$ & 444,3 & $-164,02$ & $-270,81$ & $-265,4$ & 60,86 \\
\hline 2007 & $-2,03$ & -1 & 173,32 & $-71,16$ & $-173,61$ & $-147,21$ & $-134,46$ & 488,75 & $-177,91$ & $-259,36$ & $-343,06$ & 15,75 \\
\hline 2008 & $-5,28$ & $-1,41$ & 49,97 & $-87,2$ & $-169,35$ & $-165,92$ & $-168,34$ & 477,31 & $-209,07$ & $-264,58$ & $-360,02$ & 104,65 \\
\hline 2009 & $-2,87$ & $-1,28$ & 86,04 & $-94,26$ & $-103,74$ & $-172,32$ & -155 & 457,5 & $-211,99$ & $-258,69$ & $-331,14$ & 18,04 \\
\hline 2010 & $-3,22$ & $-1,27$ & 64,64 & $-95,82$ & -96 & $-174,47$ & $-154,56$ & 578,18 & $-190,26$ & $-204,56$ & $-341,49$ & 68,72 \\
\hline 2011 & $-4,26$ & $-1,57$ & 103,01 & $-112,92$ & $-175,89$ & $-144,64$ & $-140,36$ & 555,33 & $-205,4$ & $-118,25$ & $-309,19$ & 126,48 \\
\hline 2012 & $-3,39$ & 1,01 & 116 & $-114,87$ & $-177,53$ & $-125,18$ & $-139,06$ & 663,78 & $-199,33$ & $-76,67$ & $-300,76$ & 193,47 \\
\hline 2013 & $-2,43$ & $-1,75$ & 318,88 & $-116,26$ & $-189,38$ & $-125,95$ & $-151,35$ & 674,27 & $-198,12$ & $-74,98$ & $-349,92$ & 156 \\
\hline 2014 & $-4,12$ & $-5,54$ & 44,12 & $-114,66$ & $-158,08$ & $-144,93$ & $-138,62$ & 678,15 & $-206,14$ & $-72,66$ & $-355,4$ & 140,97 \\
\hline 2015 & $-0,46$ & $-4,65$ & 464,43 & $-104,25$ & $-137,52$ & $-132,62$ & $-98,96$ & 716,01 & $-162,26$ & $-51,76$ & $-354,66$ & 147,72 \\
\hline
\end{tabular}

A first observation is that there is a trade deficit in most $\mathrm{CN}$ codes. In particular, 18 sectors have a trade deficit and only 6 a trade surplus. Trade deficits range from $-0,26$ mil $€$ (minimum value at $\mathrm{CN} 14$ in 2006) to $-1.047,33$ mil $€$ (maximum value at CN02 in 2009). Trade surpluses vary between 47,33 mil $€$ (minimum value at $\mathrm{CN03}$ in 2007) and 716,01 mil $€$ (maximum value at $\mathrm{CN} 20$ in 2015).

The sectors with the largest trade deficits are CN02-meat ( $€$ -961 million in 2015), CN23-animal feed ( $€$-354 million in 2015), CN10-cereals (€ -222 million in 2015) and CN09-coffee \& tea ( $€-197$ million in 2015). The sector with the largest trade surplus was vegetable and fruit preparations (CN20), adding up to 716 million $€$ in 2015 , followed by CN08-08 Edible fruits \& nuts with 489 mil $€$ in 2015.

A second observation is that that there are no changes in the trade balances signs pre and post crisis. This means that sectors that had a trade surplus pre crisis, continued to have a trade surplus post crisis, while the sectors that had a trade deficit pre crisis, continued to have a trade deficit post crisis. The only minor exception is at CN14 in 2012. In order to have a view of the whole Greek agrifood sector's international trade, it is useful to calculate the total trade balance for all the $24 \mathrm{CN}$ codes (Table XII and Fig. 1).

TABLE XII: TOTAL AGRIFOOD TRADE BALANCE (CN01-24)

\begin{tabular}{|c|c|c|c|c|c|}
\hline \multicolumn{5}{|c|}{ TOTAL AGRIFOOD TRADE BALANCE (MIL. $€$ ) CN01 - CN24 } \\
\hline $\mathbf{2 0 0 4}$ & $\mathbf{2 0 0 5}$ & $\mathbf{2 0 0 6}$ & $\mathbf{2 0 0 7}$ & $\mathbf{2 0 0 8}$ & $\mathbf{2 0 0 9}$ \\
\hline$-2.473,87$ & $-1.968,87$ & $-2.057,82$ & $-2.785,21$ & $-2.927,83$ & $-2.549,34$ \\
\hline $\mathbf{2 0 1 0}$ & $\mathbf{2 0 1 1}$ & $\mathbf{2 0 1 2}$ & $\mathbf{2 0 1 3}$ & $\mathbf{2 0 1 4}$ & $\mathbf{2 0 1 5}$ \\
\hline$-2.081,26$ & $-2.089,45$ & $-1.462,39$ & $-1.391,28$ & $-1.533,74$ & $-865,08$ \\
\hline
\end{tabular}

The total agrifood trade balance was negative through the examined period and ranged from a maximum of $-2.937,83$ mil $€$ in 2008 to a minimum of $-865,08$ mil $€$ in 2015 . The agrifood trade deficit decreased substantially after 2012 and especially in 2015 .

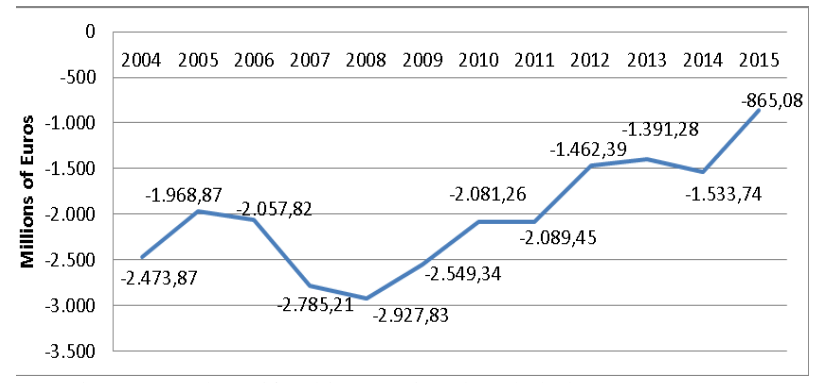

Fig. 1. Greek agrifood international trade balance (CN01-24).

\section{CONCLUSIONS}

The goal of this research was to analyze the Greek agrifood sectors' international trade performance before and after the outbreak of the recent economic crisis. Some of the research's main conclusions were the following: regarding the course of imports and exports, by comparing period averages it was concluded that imports decreased after the outbreak of the economic crisis in 9 agrifood sectors and increased in 15 . Reductions varied from $-0,5 \%$ (Preparations of vegs, fruits, nuts) to $-29 \%$ (Live animals). Increases in imports ranged from $3,65 \%$ (Meat \& edible meat offal) to $116 \%$ (Vegetable plaiting materials).

Export average values also grew in 23 out of $24 \mathrm{CN}$ categories. Increases varied from $0,70 \%$ (Tobacoo) to $249 \%$ (Live animals). Sectors that combine large export values and increases are Fish and crustaceans, Dairy produce, Edible 
fruit and nuts, Animal or vegetable fats and oils, Preparations of vegetables, fruit, nuts or other parts of plants, Miscellaneous edible preparations and Beverages, spirits and vinegar.

Only five agrifood sectors had a trade surplus (fish, oils, nuts, vegetables and fruit preparations and tobacco), while all the rest (19) had a trade deficit. Moreover, the sign of the trade balance did not change in any sector pre and post crisis. The sectors with the largest trade deficits were meat (€ -961 million in 2015), animal feed ( $€-354$ million in 2015), cereals $(€-222$ million in 2015) and coffee \& tea ( $€-197$ million in 2015). The sector with the largest trade surplus was vegetable and fruit preparations (CN20), adding up to 716 million $€$ in 2015.

For Greece, in order to improve the trade balance, there are opportunities for import replacement in the following categories: meat, animal feed and cereals. Coffee is not included because it is not produced in the country. Opportunities for increasing export value can be tracked in the sectors that have presented impressive growth during the last years, like fruits and nuts, fish, vegetable and fruit preparations, dairy products, oils and tobacco.

In order to draw further conclusions, there is need to investigate the course of imports and exports in in CN4 level, in order to uncover the exact products that led to a decrease in imports and increase in exports. Finally, there is also a need to investigate the countries that are major trading partners and record the course of international trade between Greece and them.

\section{REFERENCES}

[1] G. Vaggi and P. D. Groenewegen, A Concise History of Economic Thought, New York: Palgrave Macmillan, 2003.

[2] A. Smith, An Inquiry into the Nature and Causes of the Wealth of Nations, New York: Cosimo, 2007.

[3] D. Ricardo, On the Principles of Political Economy and Taxation, John Murray, 1817.

[4] J. S. Mill, Principles of Political Economy, Project Gutenberg, 2009.

[5] J. Frankel and D. Romer, "Does trade use growth?" American Economic Review, vol. 89, pp. 379-399, 1999.

[6] G. Mankiw, Macroeconomics, Worth Publishers, 2016.

[7] G. Meier, Biography of a Subject: An Evolution of Development Economics, Oxford, 2005.

[8] H. Thompson, International Economics: Global Markets and Competition, $2^{\text {nd }}$ ed. World Scientific Publishing Co., 2006.

[9] A. Abel, B. Bernanke, and D. Croushore, Macroeconomics, $6^{\text {th }}$ ed. Pearson, 2008.

[10] P. Krugman and M. Obstfeld, International Economics: Theory and Policy, $10^{\text {th }}$ ed. Pearson, 2009.

[11] Hellenic Statistical Authority. Greece in Figures July-September $2017 . \quad$ [Online]. Available: http://www.statistics.gr/en/greece-in-figures

[12] World Bank. World Development Indicators. [Online]. Available: http://data.worldbank.org

[13] New York Times. (July 7, 2016). Explaining Greece's Debt Crisis. [Online].

Available: https://www.nytimes.com/interactive/2016/business/international/gre ece-debt-crisis-euro.html

[14] Eurostat. (2017). Government Statistics Database, [Online]. Available http://ec.europa.eu/eurostat

[15] National Bank of Greece, Unlocking the Potential of Greek Agro-Food Industry, 2015

[16] P. Hogan. Developing the Agri-food Sector to Boost National Economic Growth in Greece. [Online]. Available: https://ec.europa.eu/commission/commissioners/2014-2019/hogan/bl og/developing-agri-food-sector-boost-national-economic-growth-gree ce_en
[17] A. Bizmpiroulas and K. Rotsios, "The Greek Food product exports: Challenges and opportunities. From FORK to farm," International Journal of the American Farm School of Thessaloniki, vol. 1, pp. 77-98, 2014

[18] World Bank. Doing Business 2017. [Online]. Available: http://www.doingbusiness.org/

[19] U. Böwer, V. Michou and C. Ungerer, The Puzzle of the Missing Greek Exports, European Commission, 2014.

[20] CNN. Olive Oil: our National Product; Interview with the Minister of Agriculture $\mathrm{Mr}$ Evaggelos Apostolou. [Online]. Available: https://www.cnn.gr/oikonomia/insights

[21] European Commission. The Combined Nomenclature. [Online] Available: https://ec.europa.eu/taxation_custom

[22] European Commission Regulation (EU) No 1101/2014.

[23] Hellenic Statistical Authority. (2017). International Trade Database. [Online]. Available: http://www.statistics.gr/

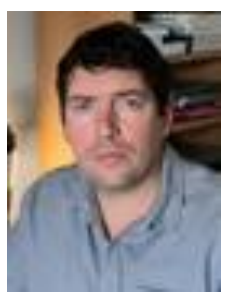

Panagiotis Kotsios holds a Ph.D. in industrial economics from the University of Macedonia in Thessaloniki, Greece in 2010. He got a bachelor of arts in economics and business policy from the University of Portsmouth in 2002, a master of science in management from the University of Teesside in 2005 , and a master in systematic philosophy from the Aristotle University of Thessaloniki in 2011. He has been working as a freelance economist since 2006, having worked for many private and public organizations in Greece. His employers include the Aristotle University of Thessaloniki, the Greek Ministry of Development, the University of Thessaly, the American Farm School of Thessaloniki and many SMEs. He is also the author of three books. His latest book titled "Entrepreneurship and Innovation: Conception, Design, Implementation and Operation" is used as textbook in several Greek universities. Currently he is a lecturer in the International Business Department of Perrotis College and in the Logistics department of the Technological Educational Institute of Central Macedonia. His research interests include entrepreneurship and competition.

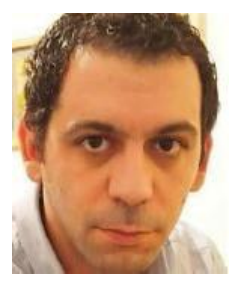

George Kartsiotis holds two BSc, two MSc and is currently a PhD candidate at the Applied Informatics department at the University of Macedonia; he received his first $\mathrm{BSc}$ is in mathematics from Aristotle University, Greece, his second BSc is in applied informatics from the University of Macedonia, Greece with honors (1st of his class), his first MSc with honours was got from the Electrical and Computer Engineering School in advanced communication and intelligent systems and his second MSc with honors was got from the Mathematics Department, Aristotle University, Greece in Theoretical Computer Science and Control Theory. He has worked for software and web development companies, with extensive experience in vocational and secondary education and he is currently an adjunct lecturer in the International Business Department of Perrotis College. His main research interests include bio inspired algorithms, optimal path planning, theoretical computer science and logic related problems.

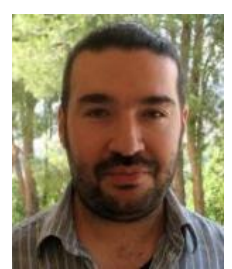

Vaios Kotsios holds a Ph.D from the National Technical University of Athens (NTUA) in the field of integrated development planning. Prior to the $\mathrm{PhD}$, he completed undergraduate studies in environmental sciences at the University of the Aegean, and postgraduate studies in Environmental and Development Sciences at NTUA and Environmental Education at the University of the Aegean. Currently he is a lecturer in the postgraduate program "Environment and Development" of the National Technical University of Athens and Associate Educational Personnel at the Open University. He has collaborated with the Athens Chamber of Commerce in projects like Open Innovation, Early Warning and mapping of business activity. He participates as a principal investigator in the Labor Market Needs Analysis Mechanism. In addition, he has developed collaborations in research projects as a principal researcher with the NTUA, Prefecture of Epirus, Prefecture of Attica, EIEAD, OAED, GSEVEE, the Municipality of Metsovo etc. His research interests are in the area of development planning. 